\title{
Examining the Link between Ethical Culture and Integrity Violations: The Mediating Role of Integrity Climate
}

\section{Afzal Izzaz Zahari, Jamaliah Said, and Roshayani Arshad}

Accounting Research Institute, Universiti Teknologi MARA, 40450 Shah Alam, Selangor, Malaysia

\section{Abstract}

Integrity violations are actions that can cause harm to the economy and society at large. These violations would cost the organisation losses or devalue their reputation. Many initiatives were taken to mitigate integrity violations at the organisation level. Creating a positive ethical culture was argued as a crucial approach to minimise the incident of integrity violations. However, to date, little research was done to provide empirical support on whether ethical culture contributes significant effect to integrity violation. This paper aims to investigate whether ethical culture can impact integrity violations. Data were collected using questionnaires distributed to 459 state

Corresponding Author: Afzal Izzaz Zahari afzalizzaz@gmail.com

Received: 5 August 2019 Accepted: 14 August 2019 Published: 18 August 2019

Publishing services provided by Knowledge E

(c) Afzal Izzaz Zahari et al. This article is distributed under the terms of the Creative Commons Attribution License, which permits unrestricted use and redistribution provided that the original author and source are credited.

Selection and Peer-review unde the responsibility of the FGIC2019 Conference Committee.

\section{G OPEN ACCESS} government departments. There are a total of 343 out of 459 (75\%) questionnaires distributed to Malaysian state government departments were received. The findings indicate that integrity climate mediates the relationship between ethical culture and integrity violations. The practicality of the research provides a further understanding of public sector organisations and their behaviours. The viewpoint of whether having ethical culture as a social norm in an organisation provides insight towards the occurrence of integrity violations.

Keywords: ethical culture, integrity climate, integrity violation, Malaysia, and public sector.

\section{Introduction}

Integrity is achieved through honest moral behaviours and related to the following key definitions of wholeness, professional, incorruptible, and with strong moral principles (Huberts, 2018). The public sector which relates to government organisations plays a vital role in maintaining actions of integrity. The people within government organisations are required to practice specific amounts of restraint towards integrity violations. This is in order for people within government organisations able to execute their work descriptions for the benefits of the stakeholders which are the people. The actions of integrity violations often cause harm than good that impacts the people within and around the organisation itself (Graaf, Huberts, \& Strüwer, 2017). Integrity violations 
are the acts of unethical, misdemeanour, procrastination, fraud, corruption and other related negative actions that are conducted by the employees within the organisation (Huberts, Kaptein, \& Lasthuizen, 2007). These violations would often cause adverse effects within the organisation itself. The common effect includes the loss of revenue or productivity towards the organisation when the person commits integrity violations such as procrastinating their work (Graaf et al., 2017) The organisations are susceptible to losses when there are substantial integrity violations such as fraud and corruption taking place. Governments such as in the United Kingdom suffer losses of up to billions of dollars due to these actions of fraud and corruption (Button, 2016). These actions are costing the government financially that these funds could have been put to better use for other activities that would have benefited the population.

Government organisations are vulnerable to integrity violations as they employed a large number of employees. The control systems of these organisations are still controlled by human actions and behaviours. The people within the organisations themselves are the ones employing the control system and choosing their level of compliance with the rules and regulation (Jokipii, 2009). The Malaysian government is susceptible to these actions of integrity violations as the government employs a rather large amount of public sector employees (Kannan, 2017). The size of the government when there are a large number of workers will increase the chances of corruption occurring (Goel \& Nelson, 1998). This would also be due to the chances that inefficiency within the government organisation itself due to large amounts of bureaucracy and systems check that are still controlled by government employees. Though current trends of research are currently observing the trends and impact of e-government towards reducing the acts of corruption and preventing these actions (Santhanamery \& Ramayah, 2012).

Cultural studies demonstrated by Geert Hofstede are focused towards cultural dimensions of individualism, power distance, masculinity, uncertainty avoidance, orientation and indulgence (Hofstede, 1980). This study involves observations towards ethical culture studies that are more focused on levels of ethics maintained within the organisation itself. The cultural values of ethical culture were evaluated through the dimension of clarity, supportability, transparency, discussability, and sanctionability (Kaptein, 2008). The problems within a culture are whether these values are the reason people are acting towards integrity violations. Past studies in China had shown that cultural values of supporting unethical activities such as corruption are allowed through the normative ethical values (Hwang, 1987; Steidlmeier, 1999). Cultural studies in Malaysia had also 
shown that gifts and favours as a social norm within the society (Ahmed, Ismail, Amin, \& Nawaz, 2013).

The study attempts to investigate the effect of ethical culture behaviours within the organisations towards integrity violations. Subsequently, this study examines the role of integrity climate as a mediator between ethical culture and integrity violations. Prior studies had observed the impact of ethical leadership towards unethical behaviour that had shown that the leadership values as an underlying factor of explanation (Mayer, Kuenzi, \& Greenbaum, 2010).

\section{Literature Review}

\subsection{Theory}

The studies of ethics and behaviour are a common approach towards understanding the principles of integrity. The meaning of integrity from the perspective of an individual or organisations would vary as the approach will have differentiating perspectives. The individual would define integrity as having honest values, ethical values and acceptable moral reasoning to which they practice in the society (Huberts, 2018). The organisational levels of integrity would involve a broader impact to the employees that involves the principle and adherence to their rules (Kolthoff, Erakovich, \& Lasthuizen, 2010). Achieving organisational integrity would prove to be beneficial as the impact would be through not just the employees but to the people surrounding the organisation itself such as the stakeholders or customers.

The social theory dictates that it is an analysis of systems, surroundings, framework and phenomena that are used to explain the social environment (Coleman, 1990). The social theory explains the reason for the actions people would make in order to choose between a rational choice or a norm-orientated decision (Reckwitz, 2007). This is to observe whether the employees within the organisation are making the decisions based on their levels of integrity or based on the social norms of the society. This is where there is a significant difference between ethics and integrity as conducting a decision which is ethical does not necessarily mean that the person is acting with integrity. The person could act with ethical values as they are following the rules and regulations although that decision would be without integrity. An example would be an employee that is following the rules of their superior although it does impact their integrity. Such actions would not be accepted towards a person that practices high levels of integrity within their persona and character. 
The acts of why people commit to unethical behaviour or integrity violations could be explained through the perspective of the fraud triangle. When there are pressure, opportunity and rationalisation the person will commit towards the act of fraud and corruption (Cressey, 1953). These values are applicable to the employees in the organisation when they have a large amount of negative cultural values. These values can be in the form of accepting the normalisation of corruption of where it is a social norm that is accepted in society (Ashforth \& Anand, 2003). The rationalisation factor here is that people will think that it is acceptable to behave towards integrity violation as it would be a social norm within their society.

\subsection{Ethical Culture}

The aspects of ethical culture involve the experience and expectation the individual practice that would impact the organisation (Kaptein, 2009). Kaptein (2007) had conceptualised the ethical-cultural values as the dimensions of clarity, supportability, transparency, discussability, and sanctionability. The values in ethical culture enable the organisation to positively impact its overall structure through projected behaviours of leaders and employees. Studies related to ethical culture had shown different stages of the approach. Past studies of ethical culture had integrated values of ethical climate that is then separated from culture (Key, 1999). Ethical culture is the shared belief within the organisation that is shared with the employees. The ethical culture studies had also shown that some values do not have a significant impact towards unethical behaviour (Kaptein, 2011). Studies of Croatian firms had shown that ethical culture would have a positive impact towards organisational climate (Silvija \& Ksenija, 2012)

The basis is whether the cultural values in terms of ethics would impact the employee's behaviour within the organisation. The practice of ethical culture is said to impact the ethical orientation of the employee that could impact their judgement (Douglas, Davidson, \& Schwartz, 2001). Through having strong leadership values in the organisation, the levels of ethical culture could be reinforced in order to have more positive values in the organisation (Toor \& Ofori, 2009). These studies had shown that cultural values in terms of ethics have a number of impacts to the organisation whether in terms of judgement, decision making and overall attitudes. This inquiry of past studies would indicate that ethical culture would have an impact towards integrity violations. 


\subsection{Integrity Climate}

Climate studies are related to the intended data collected within the organisation (D. Denison et al., 2003). The studies of climate in terms of ethical climate had been observed through various researchers that are interested in observing the effect of climate towards the organisation (Demirtas \& Akdogan, 2015; Ma'amor, Ann, Munir, \& Hashim, 2012; Peterson, 2002) These studies include the observation of the level of ethical climate towards affecting employees behaviour such as conducting deviant actions (Peterson, 2002). The climate within the organisation enables the person to conduct such integrity violations within their workplace. The organisation's climate is also able to change the employees level of commitment to work (Ma'amor et al., 2012). Their commitment to work is dependent on the level of climate portrayed in the organisation itself.

Integrity climate is the study of climate under the principals of integrity. Integrity values are strongly related to honesty, conscientiousness and principle (Zahari, Said, \& Arshad, 2019). They are related to the meaning, moral norms and rules and regulation in order to project integrity climate within the organisation itself.

Culture and climate are fundamentally not the same constructs, these two are different areas of research altogether. Climate is the experience within the organisation based on what the person see and report what is occurring to them within their direct contact (D. Denison et al., 2003). The climate structure involves what the employees perceived perception of the organisation in terms of their practices, procedures, policies, rewards, routines and other factors (Rentsch, 1990). Culture leans towards explaining on why these things occur (Schneider, 2000). Culture relates to fundamental ideologies, assumptions, and organisational events (Trice \& Beyer, 1993). Culture is an evolved concept within the organisation's system, and it is much more stable than climate and not susceptible to change (D. R. Denison, 1996).

\subsection{Integrity Violation}

The acts of negative behaviour such as procrastination, bullying, discrimination, bribery, corruption and unethical attitudes are associated with integrity violations (Huberts et al., 2007). The literature on integrity violation provides insight towards further understanding of the reasoning of human behaviour. The acts of these violations such as corruption are harmful towards the organisation and should always be kept in 
check whenever possible. Integrating preventive measures such as control systems and improving positive values will help reduce such actions of integrity violation.

Studies had shown that the acts of integrity violation are influential towards the societies environment as people are the ones viewing whether these actions are acceptable within the society (Gillanders \& Neselevska, 2018). The levels of morality within the society are indirectly affected when people in the organisation practice acts of integrity violation. For instance, government officers who are in charge of lorry transport regulations are accepting bribes in order to not take action on these errant lorry operators who had abused the law. This can be seen in the recent case with the local Road Transportation Department in Penang that had been protecting lorry drivers who had committed road offences in Penang (Anis, 2019). This is when the social norms show an impact towards the overall society as stated in prior studies of normalisation within the societal values (Ashforth \& Anand, 2003).

\section{Methodology}

\subsection{Research Model}

The Cultural Ethical Values Model (CEVM) was used to evaluate ethical culture within an organisation (Kaptein, 2008, 2009). Integrity violations are based on past studies that relate to acts of unethical behaviour conducted in the organisation (Huberts et al., 2007; Kaptein, 2011).The five virtues of ethical culture are clarity, supportability, transparency, "discussability", and "sanctionability" (Kaptein, 2008). Each of these virtues represents the ethical-cultural values that are practised in the organisation. The components of integrity climate involve values constructed from honesty, conscientiousness and principle (Zahari et al., 2019). The climate observed here in this study will serve as the mediator.

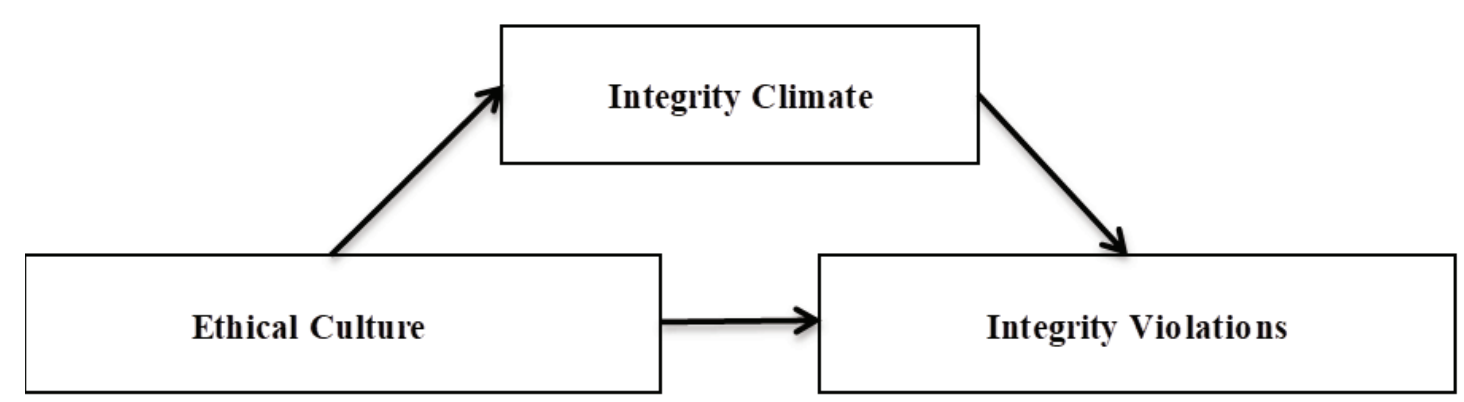

Figure 1: Conceptual Model. 
Through practising, sustainable levels of ethical culture would lead to improved moral behaviour within the organisation. Past studies indicate that ethical culture as an impact towards moral behaviour (Kaptein, 2011). The employees will behave properly when the culture within the culture projects ethical values (Key, 1999). This is where the development of the first hypothesis states that:

H1: Ethical culture will be positively related to integrity climate

Integrity climate would be able to influence the organisations proportionately when the organisation practices healthy levels of integrity climate, the employees will also have good values integrated within them. The practice of honest behaviours in the organisation would positively affect other people within the organisation (Murphy, 1993). The reflection in this attitude will have an impact towards the climate of the organisation which would then reduce the amounts of integrity violation. This leads us to the next hypothesis:

$\mathrm{H} 2$ : Integrity climate will be negatively related to integrity violation

The observation of mediation in this context is the role of integrity climate would have between ethical culture and integrity violations. This is to observe whether integrity climate serves as a source of mediation. Studies on leadership had found that ethical climate serves as a mediator between ethical leadership and employee's misconduct (Mayer et al., 2010). The last hypothesis is:

$\mathrm{H} 2$ : Integrity climate will mediate the relationship between ethical culture and integrity violations

\subsection{Sample and Data Collection}

The population of the study states that there are a total of 459 state government departments in Malaysia. A seven-point interval scale was employed ranging from 1 (strongly disagree) to 7 (strongly agree). The participants were assured that their responses are confidential and that they would not be identified individually.

TABLE 1: Demographic Profile.

\begin{tabular}{l|c|c|c|}
\multicolumn{4}{c}{ Type of position } \\
\hline Category & Qualification & Highest Qualification & Position \\
\hline Senior Management & JUSA C and above & Degree and above & CEO's \\
\hline Management & Grade 41 to 54 & Degree or Professional & Managers \\
\hline Support group A & Grade 27 to 40 & Diploma or STPM & Staff or Personnel \\
\hline Support group B & Grade 17 to 26 & SPM & Staff or Personnel \\
\hline
\end{tabular}




\begin{tabular}{|l|c|c|c|c|}
\hline & \multicolumn{3}{|c|}{ Gender } & \\
& Frequency & Percent & Valid Percent & $\begin{array}{c}\text { Cumulative } \\
\text { Percent }\end{array}$ \\
\hline Male & 150 & 43.7 & 43.7 & 44.9 \\
\hline Female & 189 & 43.7 & 43.7 & 100.0 \\
\hline Total & 343 & 100.0 & 100.0 & \\
\hline
\end{tabular}

\begin{tabular}{|c|c|c|c|c|}
\hline \multicolumn{5}{|c|}{ Education Qualification } \\
\hline & Frequency & Percent & Valid Percent & $\begin{array}{c}\text { Cumulative } \\
\text { Percent }\end{array}$ \\
\hline SPM & 33 & 9.6 & 9.6 & 15.7 \\
\hline STPM & 9 & 2.6 & 2.6 & 18.3 \\
\hline Diploma & 88 & 25.7 & 25.7 & 44 \\
\hline Degree & 146 & 42.6 & 42.6 & 86.6 \\
\hline Masters & 42 & 12.2 & 12.2 & 98.8 \\
\hline $\mathrm{PhD}$ & 4 & 1.2 & 1.2 & 100.0 \\
\hline Total & 343 & 100.0 & 100.0 & \\
\hline
\end{tabular}

\begin{tabular}{|c|c|c|c|c|}
\hline \multicolumn{5}{|c|}{ Age } \\
\hline & Frequency & Percent & Valid Percent & $\begin{array}{c}\text { Cumulative } \\
\text { Percent }\end{array}$ \\
\hline 20-30 Years & 44 & 12.8 & 12.8 & 14.0 \\
\hline $31-40$ Years & 180 & 52.5 & 52.5 & 66.5 \\
\hline 41-50 Years & 80 & 23.3 & 23.3 & 89.8 \\
\hline 51 and above & 35 & 10.2 & 10.2 & 100.0 \\
\hline Total & 343 & 100.0 & 100.0 & \\
\hline
\end{tabular}

\begin{tabular}{|c|c|c|c|c|}
\hline \multicolumn{5}{|c|}{ Position } \\
\hline & Frequency & Percent & Valid Percent & $\begin{array}{c}\text { Cumulative } \\
\text { Percent }\end{array}$ \\
\hline Grade 17 to Grade 26 & 74 & 21.6 & 21.6 & 30.0 \\
\hline Grade 27 to Grade 40 & 82 & 23.9 & 23.9 & 53.9 \\
\hline Grade 41 to Grade 54 & 153 & 44.6 & 44.6 & 98.5 \\
\hline JUSA $C$ and above & 5 & 1.5 & 1.5 & 100 \\
\hline Total & 343 & 100 & 100 & \\
\hline
\end{tabular}

\begin{tabular}{|l|c|c|c|c|}
\hline & \multicolumn{3}{|c|}{ Years of Service } \\
& Frequency & Percent & Valid Percent & $\begin{array}{c}\text { Cumulative } \\
\text { Percent }\end{array}$ \\
\hline Less than 5 years & 49 & 14.3 & 14.3 & 14.9 \\
\hline 6 to 10 years & 83 & 24.2 & 24.2 & 39.1 \\
\hline 11 to 15 years & 105 & 30.6 & 30.6 & 69.7 \\
\hline More than 15 years & 104 & 30.3 & 30.3 & 100.0 \\
\hline Total & 343 & 100.0 & 100.0 & \\
\hline
\end{tabular}


Table 1 shows the overall profile of the respondents. The senior management comprises of officers who have the responsibilities of a Chief Executive Officer (CEO) in their organisation. They normally hold positions such as the head of directors, state secretaries or head of departments. Management is people who hold positions such as directors, assistant directors, and or head of units. The support group are mostly officers who are holding executive equivalent positions. The state department's demographic distribution table shows that female respondents exceed by 39 male respondents. The highest number of people holds degree certifications while philosophical degree holders are only four people in the mixture. The second highest amount of qualification goes to diploma holders with 88 people. The majority of the respondents are between the ages of 31 to 40 years old. Those people aged 51 above are the smallest portion with 35 respondents. The majority of the respondents are also people who held positions of grades from 41 to 54 . Only 5 people are holding positions of JUSA and above. The large portions of the respondents have also served the government for more than five years.

There are a total of $\mathbf{4 5 9}$ state government departments in Malaysia. These state departments are the government departments that report directly to the state secretary. The constructs of the state department comprise of departments, offices, corporations ("perbadanan"), council, foundation and commissions that are under the state department leadership (Department of Information Malaysia, 2017). There are two sets of questionnaires per department that were delivered to each of the state departments. This is where one is to be returned and one to be kept for their departmental records. There are a total of 343 people who represented these state government departments that had answered the survey questionnaire.

\section{Results and Analysis}

\subsection{Descriptive statistics}

The means, standard deviations and inter-correlations among the key variables are presented in the following table

\subsection{Convergent Validity}

The use of convergent validity is the assessment to measure the level of correlation of multiple indicators of the same construct that are in agreement. In order to evaluate 
TABLE 2: Descriptive Statistics and Correlations Among Variables.

\begin{tabular}{l|c|c|c|c|c|}
\hline Variables & Mean & SD & $\begin{array}{c}\text { Ethical } \\
\text { Culture }\end{array}$ & $\begin{array}{c}\text { Integrity } \\
\text { Climate }\end{array}$ & $\begin{array}{c}\text { Integrity } \\
\text { Violations }\end{array}$ \\
\hline Ethical Culture & 5.37 & 1.26 & 1 & 0.82 & -0.083 \\
\hline Integrity Climate & 5.38 & 1.24 & & 1 & -0.232 \\
\hline Integrity Violations & 2.72 & 1.46 & & & 1 \\
\hline Note: $\mathrm{N}=$ 343. All correlations are significant at $\mathrm{p}<0.001$ (2-tailed) &
\end{tabular}

establish convergent validity, the factor loading of the indicator, composite reliability (CR) and the average variance extracted (AVE) have to be evaluated and assessed. The value range of $C R$ should be between 0 and 1 and AVE should exceed 0.50 to have an adequate convergence (Hair, Anderson, Tatham, \& Black, 2010)

TABLE 3: Convergent Test.

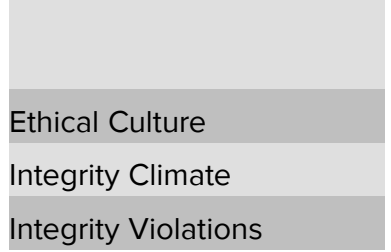

\begin{tabular}{|c|}
\hline Cronbach's Alpha \\
\hline 0.987 \\
0.974 \\
0.978
\end{tabular}

$\begin{gathered}\text { Average Variance } \\ \text { Extracted (AVE) } \\ 0.762 \\ 0.828 \\ 0.66\end{gathered}$

The values of each of the latent variable indicated that each is within the acceptable threshold. The convergent validity is then confirmed.

\subsection{Discriminant Validity}

Discriminant validity is the measurement to show that the construct and variables are not related to each other (O'Donohoe \& Neijens, 2012). The purpose is to show that each of the constructs is distinct from each other throughout the model. The variables used within the study should have their validity in order to be evaluated with one another, if the item has the same construct or similar, then the variable should be removed within the general model. The assessment of discriminant validity in the variable through the structural equation modeling was through the use of heterotrait-monotrait ratio (HTMT). The HTMT is a recent assessment technique that was introduced within the SmartPLS version 3 software which enables such evaluation as compared to the traditional Fornell and Larcker criterions. Studies had observed that the use of HTMT was more strict towards its evaluation as compared to the other method (Abdul Hamid, Sami, \& Sidek, 2017).

The HTMT criterion states that the threshold of value is 1 (Alarcón \& Sánchez, 2015). When the values within the results are less than 1, then this indicates that these are 
different factors. The lower the amount or value is, the more distinct the items are with each other.

TABLE 4: Discriminant Validity.

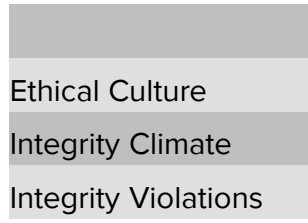

Ethical Culture
$\begin{gathered}0.819 \\ 0.258\end{gathered}$
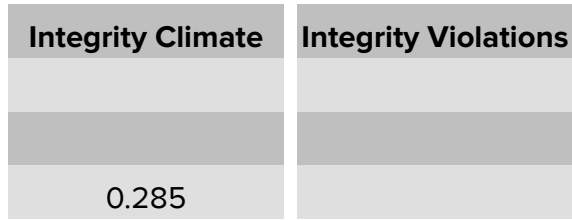

The variables within the data of federal respondents indicate that each of the constructs is different from each other. The smaller values than 1 within the results shows that the true correlation between the constructs should differ.

\subsection{Model Fit}

The software used for data analysis is the SmartPLS version in order to test the hypothesis. Prior to the testing of the hypothesized model, the model was tested in terms of model fit (Hooper, Coughlan, \& Mullen, 2008). The model was tested through the three latent factors (i.e. ethical culture, integrity climate and integrity violations) and 59 indicators (25 items for ethical culture, 9 items for integrity climate and 25 items for integrity violations). The measurement model had an acceptable model fit.

TABLE 5: Goodness of Fit Indices for the Model.

Goodness of fit measure
SRMR
NFI

Recommended value
$<0.08$
Closer to 1 is better

Estimated Model
0.047
0.715

\subsection{Hypothesis Test}

TABLE 6: Hypothesis Testing.

\begin{tabular}{|c|c|c|c|c|}
\hline Hypothesis & Path coefficient & T-statistics ${ }^{1}$ & $\mathbf{P}^{2}$ & Result $^{3}$ \\
\hline & Ethical Culture $->$ Integrity Violations & 0.785 & 0.432 & \\
\hline $\mathrm{H} 1$ & Ethical Culture $->$ Integrity Climate & 27.879 & $* *$ & Accept \\
\hline \multirow[t]{2}{*}{$\mathrm{H} 2$} & Integrity Climate $->$ Integrity Violations & 2.292 & $* *$ & Accept \\
\hline & Total indirect effects & T-statistics ${ }^{1}$ & $P^{2}$ & Result $^{3}$ \\
\hline $\mathrm{H} 3$ & Ethical Culture $->$ Integrity Violations & 2.222 & $* *$ & Accept \\
\hline \multicolumn{5}{|c|}{ T-statistics ${ }^{1} \quad$ Size of the difference relative to the variation } \\
\hline \multicolumn{5}{|c|}{$\mathrm{P}^{2} \quad{ }^{* *}$ Significant at $(\mathrm{p}<0.05)$} \\
\hline \multicolumn{5}{|c|}{ Result $^{3} \quad$ Results on hypothesis test } \\
\hline
\end{tabular}


The partial mediated model was compared to a fully mediated model. The partial mediated model was through using a direct path between ethical culture and integrity violations. Through the results as stated in the previous table (Table 6), there was no significant direct effect of ethical culture on integrity violations when testing the partially mediated model. The rules of parsimony state that a fully mediated model is a better fitting model for examining these data (James, Mulaik, \& Brett, 2016).

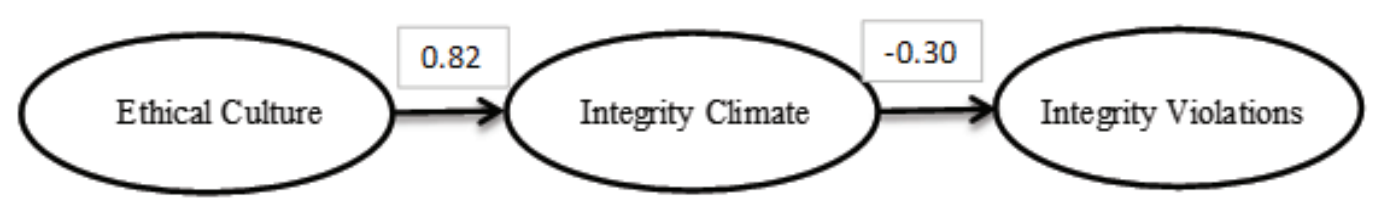

Figure 2: Fully Mediated Structural Equation Model Results (Note: Standardized path coefficients provided. All path coefficients significant at $p \leq 0.001)$.

The first hypothesis $(\mathrm{H} 1)$ shows that the path coefficient between ethical culture and integrity climate $(p \leq 0.05)$ was positive and significant. The second supported hypothesis $(\mathrm{H} 2)$ predicted that integrity climate is negatively related to integrity violations $(p \leq 0.05)$. The third hypothesis $(H 3)$ predicted that integrity climate mediates the relationship between ethical culture and integrity violations. In order to test for the mediation, there must first be a statistically significant relationship between the predictor and mediator ( James et al., 2016). The second rule also states that there must be a significant relationship between the mediator and the outcome. The model fit must also be tested to investigate whether the path from the predictor exists only through the mediator. The results provided the support that integrity climate acts as a mediator for the relationship between ethical culture and integrity violations.

\subsection{PLS Model}

\section{Discussion}

The issues of integrity violation within organisations are often considered a thorn and management and governmental organisations are always evolving in order to mitigate these problems. Studies on the effectiveness of control systems to control the environment had shown some effectiveness towards handling unethical behaviours and efficiency (Yurniwati \& Rizaldi, 2015). The findings based on the hypothesis clearly states that ethical culture was positively related to integrity climate, integrity climate was then negatively related to integrity violations, and integrity climate mediated the 


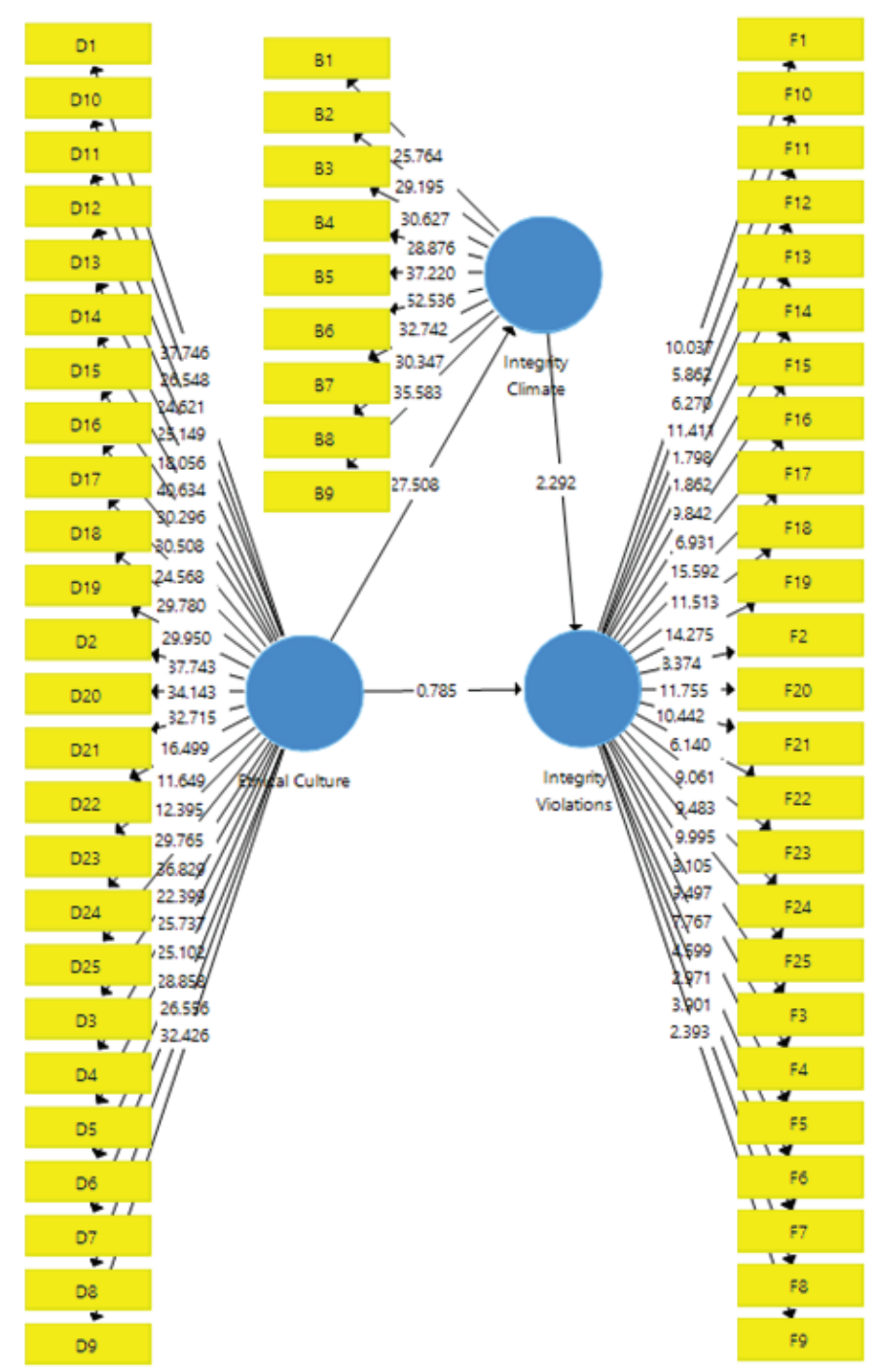

Figure 3: Hypothesized PLS Path Model.

relationship between ethical culture and integrity climate. The following section provides the impact towards the theoretical and practical impact of this study.

The study shows us some of the theoretical implications concerning the studies of culture within organisations. The result states that there is no significant relationship between ethical culture and integrity violations. The levels of ethical culture within employees would not have an impact on their action to commit an act of integrity violation. The findings suggest that the climate such as having an environment of integrity not only reduces the acts of integrity violation but also mediates the relationship between ethical culture and integrity violation. The statement here suggests that it would be best to promote immediate positive values in the organisation such as honesty and truthfulness in order to improve organisational levels of integrity. 
Through the knowledge that ethical culture does not reduce integrity violations, it does however positive correlates with integrity climate. The management or leaders in the organisation should set a tone for more ethical culture behaviour within the organisation. Promoting actions such as through transparency and ethical supportability would improve the overall levels of integrity climate. The motivations to create an environment full of integrity should be implemented amongst the employees in order to reduce the rates of integrity violation. The organisation should further implement methods on how to improve the levels of integrity climate through the promotion of ethical culture amongst the employees.

The impact of integrity violations as stated in the earlier section of this paper shows a significant amount of losses for the organisation (Button, 2016). There is a need for observing effective methods of reducing integrity violations amongst organisational employees. The method should cover the overall effect and not just only focus on individual improvements. Improving the overall ethical culture will indirectly reduce the rate of integrity violations in an organisation. The result of this study suggests the areas of improvement in ethical culture that can be utilised to create a climate of integrity in the organisation.

The integrity climate will be able to be positively influenced when there is a positive ethical culture maintained within the organisation. The leaders can show positive ethical culture through becoming a mentor or role model themselves. This is shown in a previous study that directions of culture in an organisation depend on the tone of the leadership at the top management (Staicu, Tatomir, \& Lincă, 2013). Through the influence of positive ethical culture, the overall climate will be improved that has an impact on the whole organisation (Shafer \& Simmons, 2011). Maintaining a positive ethical culture in an organisation will bring forwards direct benefits where integrity violations can be controlled.

\subsection{Limitations and Recommendation for Future Research}

The drawback of this study is that the sample was only using government department employees. Though the limited sample was only towards government employees, there are further opportunities of including other sectors of industries such as the private sector or through specific areas of industry. Future research should focus on the effect of culture on positive behaviours as this study analysed the impact towards negative actions such as integrity violations. The difference is sample target may provide different 
results as there are different motivations between private and public sector employees (Frank \& Lewis, 2004).

\section{Acknowledgement}

We are indebted to the Malaysian Institute of Integrity (IIM) and the Accounting Research Institute (ARI, UiTM) in giving us the support needed for this project. We appreciate the reviews and comments made by academicians on earlier drafts of this paper. Special thanks to the participating government agency, organisations and commissions that participated in this project.

\section{References}

[1] Abdul Hamid, M. R., Sami, W., \& Sidek, M. H. M. (2017). Discriminant Validity Assessment: Use of Fornell \& Larcker criterion versus HTMT Criterion. Journal of Physics: Conference Series, 890(1), 12163. https://doi.org/1742-6596

[2] Ahmed, I., Ismail, W. K. W., Amin, S. M., \& Nawaz, M. M. (2013). A Social Exchange Perspective of the Individual Guanxi Network: Evidence from Malaysian-Chinese employees. Chinese Management Studies, 7(1), 127-140. https://doi.org/10.1108/ 17506141311307640

[3] Alarcón, D., \& Sánchez, J. A. (2015). Assessing Convergent and Discriminant Validity in the ADHD-R IV Rating Scale: User-Written Commands for Average Variance Extracted (AVE), Composite Reliability (CR), and Heterotrait-Monotrait Ratio of Correlations (HTMT). Spanish STATA Meeting 2015, 1-39.

[4] Anis, M. N. (2019). MACC Arrests 31, including Road Transportation Department Officers. The Star Online, p. 1. Retrieved from https://www.thestar.com.my/news/ nation/2019/04/16/macc-arrests-31-including-rtd-officers/

[5] Ashforth, B. E., \& Anand, V. (2003). The Normalization of Corruption in Organizations. Research in Organizational Behavior, 25(03), 1-52. https://doi.org/10.1016/S01913085(03)25001-2

[6] Button, M. (2016). Fraud costing UK economy £193bn a year. Retrieved from http: //uopnews.port.ac.uk/2016/05/25/fraud-costing-uk-economy-193bn-a-year/

[7] Coleman, J. S. (1990). Foundation of Social Theory. Book. https://doi.org/10.2307/ 2579680

[8] Cressey, D. R. (1953). Other People's Money: A study of the social psychology of embezzlement. Free Press. Retrieved from http://psycnet.apa.org/psycinfo/1954- 
06293-000

[9] Demirtas, O., \& Akdogan, A. A. (2015). The Effect of Ethical Leadership Behavior on Ethical Climate, Turnover Intention, and Affective Commitment. Journal of Business Ethics, 130(1), 59-67. https://doi.org/10.1007/s10551-014-2196-6

[10] Denison, D., Ashkanasy, N., Wilderom, C., Peterson, M., Cooper, C. L., Cartwright, S., \& Earley, P. C. (2003). The Handbook of Organizational Culture and Climate. Administrative Science Quarterly (Vol. 48). https://doi.org/10.1017/CBO9781107415324.004

[11] Denison, D. R. (1996). What is the Difference Between Organizational Culture and Organizational Climate? A native's point of view on a decade of paradigm wars. Academy of Management Review, 21(3), 619-654.

[12] Department of Information Malaysia. (2017). Senarai Jabatan atau Agensi Kerajaan Persekutuan. Retrieved May 25, 2017, from http://pmr.penerangan.gov.my/index. php/maklumat-kenegaraan/12071-senarai-jabatanagensi-kerajaan-persekutuan. html

[13] Douglas, P. C., Davidson, R. A., \& Schwartz, B. N. (2001). The Effect of Organizational Culture and Ethical Orientation on Accountants' Ethical Judgement. Journal of Business Ethics, 34(2), 101-121.

[14] Frank, S. A., \& Lewis, G. B. (2004). Government Employees: Working Hard or Hardly Working? The American Review of Public Administration, 34(1), 36-51. https://doi. org $/ 10.1177 / 0275074003258823$

[15] Gillanders, R., \& Neselevska, O. (2018). Public Sector Corruption and Trust in the Private Sector. Journal of International Development, 30(8), 1288-1317. https://doi. org/10.1002/jid.3306

[16] Goel, R. K., \& Nelson, M. A. (1998). Corruption and Government Size: A disaggregated analysis. Public Choice, 97, 107-120. https://doi.org/10.1023/A:1004900603583

[17] Graaf, G. de, Huberts, L., \& Strüwer, T. (2017). Integrity Violations and Corruption in Western Public Governance: Empirical Evidence and Reflection from the Netherlands. Public Integrity, O(0), 1-19. https://doi.org/10.1080/10999922.2017. 1350796

[18] Hair, J. F., Anderson, R. E., Tatham, R. L., \& Black, W. C. (2010). Multivariate Data Analysis: A global perspective. Upper Saddle River (7th Editio). New Jersey: Prentice Hall.

[19] Hofstede, G. (1980). Culture's consequences: International differences in workrelated values. Canada: SAGE Publications Limited. 
[20] Hooper, D., Coughlan, J., \& Mullen, M. R. (2008). Structural Equation Modelling: Guidelines for Determining Model Fit. The Electronic Journal of Business Research Methods, 6(1), 53-60. https://doi.org/10.1037/1082-989X.12.1.58

[21] Huberts, L. (2018). Integrity: What it is and Why it is Important. Public Integrity. https: //doi.org/10.1080/10999922.2018.1477404

[22] Huberts, L., Kaptein, M., \& Lasthuizen, K. (2007). A Study of The Impact of Three Leadership Styles on Integrity Violations Committed by Police Officers. Policing: An International Journal of Police Strategies \& Management, 30(4), 587-607. https: //doi.org/10.1108/13639510710833884

[23] Hwang, K. (1987). Face and Favor: The Chinese Power Game. American Journal of Sociology, 92(4), 944-974. https://doi.org/10.1086/228588

[24] James, L. R., Mulaik, S. A., \& Brett, J. M. (2016). A Tale of Two Methods: Different strategies of testing for mediation. Organizational Research Methods, 9(2), 233-244. https://doi.org/10.1177/1094428105285144

[25] Jokipii, A. (2009). Determinants and Consequences of Internal Control in Firms: A contingency theory based analysis. Journal of Management and Governance, 14(2), 115-144. https://doi.org/10.1007/s10997-009-9085-x

[26] Kannan, H. K. (2017). Johari denies saying number of civil servants have led to decreased productivity. New Straits Times Online, p. 1. Retrieved from https://www.nst.com.my/news/2017/02/213350/johari-denies-saying-numbercivil-servants-have-led-decreased-productivity

[27] Kaptein, M. (2008). Developing and Testing a Measure for the Ethical Culture of Organizations: The Corporate Ethical Virtues Model. Journal of Organizational Behavior, 29(7), 923-947.

[28] Kaptein, M. (2009). Ethics programs and Ethical culture: A next step in unraveling their multi-faceted relationship. Journal of Business Ethics, 89(2), 261-281. https: //doi.org/10.1007/s10551-008-9998-3

[29] Kaptein, M. (2011). From Inaction to External Whistleblowing: The Influence of the Ethical Culture of Organizations on Employee Responses to Observed Wrongdoing. Journal of Business Ethics, 98(3), 513-530. https://doi.org/10.1007/s10551-010-05911

[30] Key, S. (1999). Organizational Ethical Culture: Real or imagined? Journal of Business Ethics, 20(3), 217-225. https://doi.org/10.1023/A:1006047421834

[31] Kolthoff, E., Erakovich, R., \& Lasthuizen, K. (2010). Comparative Analysis of Ethical Leadership and Ethical Culture in Local Government. International Journal of Public Sector Management, 23(7), 596-612. https://doi.org/10.1108/09513551011078879 
[32] Ma'amor, H., Ann, H. J., Munir, R. I. S., \& Hashim, N. (2012). The Relationship between Ethical Climates and Organizational Commitment in Manufacturing Companies. International Proceedings of Economics Development and Research, 56, 134-138. https://doi.org/10.7763/IPEDR.

[33] Mayer, D. M., Kuenzi, M., \& Greenbaum, R. L. (2010). Examining the Link Between Ethical Leadership and Employee Misconduct: The Mediating Role of Ethical Climate. Journal of Business Ethics, 95(SUPPL. 1), 7-16. https://doi.org/10.1007/s10551-0110794-0

[34] Murphy, K. R. (1993). Honesty in the workplace. Brooks/Cole Belmont, CA.

[35] O'Donohoe, S., \& Neijens, P. (2012). Handbook of Research on International Advertising. International Journal of Advertising, 31(3), 681-682. https://doi.org/10. 2501/ija-31-3-681-682

[36] Peterson, D. K. (2002). Deviant Workplace Behavior and the Organizations Ethical Climate. Journal of Business and Psychology, 17(1), 47-61. https://doi.org/08893268/02/0900-0047/0

[37] Reckwitz, A. (2007). Toward a Theory of Social Practices: A Development in Culturalist Theorizing. European Journal of Social Theory, 5(2), 243-263. https: //doi.org/10.1177/13684310222225432

[38] Rentsch, J. R. (1990). Climate and Culture: Interaction and qualitative differences in organizational meanings. Journal of Applied Psychology, 75(6), 668.

[39] Santhanamery, T., \& Ramayah, T. (2012). Continued Usage Intention of E-Filing System in Malaysia: The Role of Optimism Bias. Procedia - Social and Behavioral Sciences, 65(ICIBSoS), 397-403. https://doi.org/10.1016/j.sbspro.2012.11.140

[40] Schneider, B. (2000). The Psychological Life of Organizations. Handbook of Organizational Culture and Climate, 17-21.

[41] Shafer, W. E., \& Simmons, R. S. (2011). Effects of Organizational Ethical Culture on the Ethical Decisions of Tax Practitioners in Mainland China. Accounting, Auditing \& Accountability Journal, 24(5), 647-668. https://doi.org/10.1108/09513571111139139

[42] Silvija, V., \& Ksenija, D. (2012). Testing How Ethical Culture Impacts Organizational Climate: The Case Of Croatian Firms. In International OFEL Conference on Governance, Management and Entrepreneurship (pp. 671-686).

[43] Staicu, A. M., Tatomir, R. I., \& Lincă, A. C. (2013). Determinants and Consequences of “ Tone at the Top." International Journal of Advances in Management and Economics, 2, 76-88.

[44] Steidlmeier, P. (1999). Gift Giving, Bribery and Corruption in China. Journal of Business Ethics, 121-132. 
[45] Toor, S. ur R., \& Ofori, G. (2009). Ethical Leadership: Examining the relationships with full range leadership model, employee outcomes, and organizational culture. Journal of Business Ethics, 90(4), 533-547. https://doi.org/10.1007/s10551-009-0059-3

[46] Trice, H. M., \& Beyer, J. M. (1993). The Cultures of Work Organizations. Prentice-Hall, Inc.

[47] Yurniwati, \& Rizaldi, A. (2015). Control Environment Analysis at Government Internal Control System: Indonesia Case. Procedia - Social and Behavioral Sciences, 211(September), 844-850. https://doi.org/10.1016/j.sbspro.2015.11.111

[48] Zahari, A., Said, J., \& Arshad, R. (2019). Integrity Climate Questionnaire. Cogent Psychology, 25. https://doi.org/10.1080/23311908.2019.1626541. 